\title{
ANALISIS RAPD KECIPIR POLONG PANJANG Psophocarpus tetragonolobus (L.) DC HASIL MUTASI IRADIASI SINAR GAMMA
}

\author{
Arini Maesaroh, Adi AmurWanto, Alice Yuniaty
}

Fakultas Biologi, Universitas Jenderal Soedirman, Jalan dr. Suparno 63 Purwokerto 53122

\section{A B S T R A C T}

Winged bean [Psophocarpus tetragonolobus (L.) DC] is a tropical plant that has some benefits and is very suitable to be cultivated in Indonesia. Study about diversity of winged bean is very important to support the future development of winged bean. Increased genetic diversity can be done through mutation. Gamma ray is often used for inducing mutations. One of way to observe genetic diversity resulted by molecular mutation is using RAPD method. The purpose of this study was to identify the genetic diversity of winged bean resulted by gamma ray irradiation. The method used in this study was an experiment by using RAPD technique. Samples used were plant leaves that had been induced by gamma ray with wavelength of $20 \mathrm{~Gy}, 25 \mathrm{~Gy}$, and control plants that were not induced by gamma ray. RAPD were done by ten primers that were OPA 9, OPA 10, OPA 13, OPA 18, OPB 2, 3 OPB, OPB 6, 7 OPB, OPB 10, and OPB 11 . Data were analyzed using GenAlex 6.1 Program. The percentage of polymorphic loci of winged bean population control was 47,54\%, while in the 20 and $25 \mathrm{~Gy}$ treatment were $62,30 \%$ and $54,10 \%$, respectively. The values of genetic variation based on the calculation of allele frequencies were 0,236; 0,202 and 0,194 for treatment of $20 \mathrm{~Gy}, 25 \mathrm{~Gy}$ and for control plants, respectively. Meanwhile, the value of genetic distance ranged from 0.08 to 0.32 .

KEY WORDS: winged bean, genetic diversity, mutation, gamma rays, RAPD

Penulis korespondensi: ARINI MAESAROH | email: arinimaesaroh89@gmail.com

\section{PENDAHULUAN}

Tanaman kecipir sudah dikenal di Indonesia meskipun belum dibudidayakan secara luas. Menurut Rismunandar (1983), secara umum penanaman kecipir masih sangat terbatas. Meskipun demikian, kecipir merupakan tanaman yang potensial bagi perbaikan gizi masyarakat. Menurut Rukmana (2000), beberapa manfaat kecipir antara lain, sebagai bahan makanan manusia, obat tradisional, dan pakan ternak. Selain itu, kecipir juga bermanfaat sebagai tanaman penyubur tanah, penahan erosi, tanaman penutup tanah dan pembasmi gulma.

Kecipir memiliki nilai gizi yang amat baik. Kandungan gizi kecipir antara lain protein, lemak, karbohidrat, kalsium, fosfor, zat besi, vitamin A, vitamin B1 dan vitamin C. Proporsi kandungan protein, lemak dan karbohidrat biji kecipir lebih unggul dibandingkan daging sapi, domba dan kacangkacangan lainnya (Direktorat Gizi Depkes RI, 1981 dalam Rukmana, 2000).

Sentra tanaman kecipir diperkirakan dari Papua Nugini, Mauritius, Madagaskar, dan India (Krisnawati, 2010). Meskipun telah lama dikenal oleh masyarakat Indonesia, hingga saat ini kecipir belum dibudidayakan secara luas. Oleh karena itu, luas pertanaman kecipir, potensi hasil maupun keuntungan budidaya kecipir belum diketahui secara jelas. Berbeda dengan negara lain yang telah membudidayakan kecipir secara komersial, seperti Myanmar dan Nigeria, dengan potensi hasil 35,50-40 ton polong muda/ha atau setara dengan 4,50 ton biji kering/ha (Rukmana, 2000).

Pemuliaan tanaman memiliki peranan penting dalam industri pertanian, khususnya dalam perakitan varietas-varietas unggul. Teknik mutasi merupakan salah satu metode pemuliaan tanaman yang banyak digunakan. Teknik ini menggunakan bahan mutagen, seperti sinar gamma, untuk menginduksi terjadinya mutasi pada tanaman. Mutasi dapat meningkatkan keragaman genetik tanaman. Mutan-mutan yang dihasilkan kemudian dapat dijadikan sebagai populasi dasar untuk seleksi dalam program pemuliaan lebih lanjut. Pemuliaan tanaman dengan teknik mutasi telah menghasilkan banyak varietas mutan tanaman komersial. Sinar gamma merupakan radiasi elektromagnetik yang berasal dari radioisotop dan reaksi nuklir. Energinya mencapai beberapa $\mathrm{MeV}$ dan daya tembusnya banyak dalam hitungan sentimeter (Soeranto, 2003). Beberapa penelitian pemuliaan menggunakan teknik induksi mutasi telah menghasilkan antara lain mutan kedelai M6 yang toleran kekeringan dan berdaya hasil tinggi (Balai Besar Penelitian dan Pengembangan Bioteknologi dan Sumberdaya Genetik Pertanian, 2011).

Metode RAPD (Random Amplified Polymorphic $D N A$ ) adalah metode untuk menghasilkan profil finger printing DNA dengan menggunakan primer acak yang banyak digunakan dalam berbagai studi keragaman genetik (Pratiwi, 2012). Williams et al. (1990), telah mengembangkan metode RAPD (Random Amplified Polymorphic DNA) untuk menghasilkan marker polimorfik yang tepat dan dapat digunakan untuk menentukan variasi dan kekerabatan genetik pada tumbuhan. Menurut Nair et al. (2002), metode PCR RAPD banyak digunakan untuk analisis keragaman genetik. Koshy et al. (2013) menggunakan marka RAPD untuk amplifikasi DNA dari plantlet invitro kecipir untuk mengevaluasi kestabilan genetiknya.

Induksi mutasi merupakan teknik yang telah banyak digunakan dalam pengembangan berbagai komoditi dan sangat cepat untuk meningkatkan keanekaragaman genetik. Kecipir memiliki potensi yang besar, namun belum dimanfaatkan secara 
optimal. Berdasarkan latar belakang di atas dapat dirumuskan permasalahan yaitu; bagaimana profil RAPD tanaman kecipir hasil mutasi iradiasi sinar gamma, dan bagaimana keragaman genetik kecipir hasil iradiasi sinar gamma. Terkait dengan hal tersebut, penelitian ini akan dilaksanakan dengan tujuan sebagai berikut:

1. Mengetahui profil RAPD tanaman kecipir hasil mutasi iradiasi sinar gamma.

2. Mengetahui keragaman genetik kecipir hasil iradiasi sinar gamma.

Penelitian ini diharapkan dapat digunakan sebagai sumber informasi mengenai keragaman genetik kecipir hasil mutasi menggunakan iradiasi sinar gamma. Mutasi adalah terjadinya perubahan materi genetik suatu makhluk yang terjadi secara acak dan merupakan dasar bagi sumber variasi organisme hidup yang bersifat terwariskan (Soeranto, 2003). Menurut IAEA (1977), mutasi dapat terjadi secara spontan di alam dan melalui induksi. Mutagen yang sering digunakan dalam penelitian pemuliaan tanaman adalah mutagen kimia seperti, senyawa alkil (EMS, dES, MMS, dan lain-lain) dan juga mutagen fisika yang bersifat sebagai radiasi pengion seperti, sinar-X, radiasi gamma, radiasi beta, neutrons dan lain-lain. Induksi mutasi merupakan teknik yang cepat untuk menghasilkan keragaman genetik. Hartanti (2012), dalam penelitiannya menggunakan EMS sebagai mutagen untuk menghasilkan variasi genetik pada kecipir. Namun, variasi yang dihasilkan tidak terlalu signifikan. Sinar gamma merupakan mutagen fisik yang daya tembusnya sangat besar sehingga diharapkan induksi mutasi dengan iradiasi sinar gamma dapat menghasilkan variasi yang lebih signifikan. Penelitian Sulistiyaningsih et al. (2012) terhadap anggrek bulan hasil iradiasi sinar gamma dosis 15 dan 40 Gy dengan teknik RAPD menunjukkan variabilitas genetik tinggi dibandingkan tanpa perlakuan.

\section{METODE}

Metode penelitian yang digunakan pada penelitian ini adalah eksperimen dengan menggunakan teknik RAPD. Sampel berupa daun tanaman kecipir yang telah diinduksi sinar gamma dengan panjang gelombang $20 \mathrm{~Gy}, 25 \mathrm{~Gy}$ dan tanaman kontrol yang tidak diinduksi sinar gamma. Masingmasing perlakuan menggunakan 5 sampel tanaman.

Tanaman kecipir yang digunakan merupakan koleksi Laboratorium Genetika Fakultas Biologi Universitas Jenderal Soedirman. Sampel tanaman kecipir terdiri atas tanaman kontrol dan tanaman yang ditumbuhkan dari biji yang telah diberi perlakuan iradiasi sinar gamma. Induksi mutasi biji kecipir dilakukan di BATAN, Jakarta.

1. Pengambilan sampel daun kecipir. Daun kecipir muda dan segar diambil dari tanaman kontrol, dan tanaman yang telah diinduksi sinar gamma 20 Gy dan 25 Gy, dimasukkan ke dalam amplop yang diberi silica gel.

2. Isolasi DNA genom kecipir. Sampel daun kecipir yang digunakan sebanyak 0,05 gr. Isolasi DNA genom dilakukan menggunakan metode CTAB Doyle and Doyle (1990) yang telah dimodifikasi oleh laboratorium Genetika dan Pemuliaan Tanaman, Fakultas Pertanian Universitas Gajah Mada.
3. Kuantifikasi DNA. Kuantifikasi adalah prosedur untuk mengetahui konsentrasi dan kualitas DNA yang telah diekstraksi. Alat yang digunakan untuk kuantifikasi adalah spektrofotometer Genequant 1300. Sebelum dilakukan pengukuran, kuvet dibersihkan terlebih dahulu menggunakan alkohol dan aquabides serta dilakukan kalibrasi. Untuk menghitung konsentrasi DNA, $2 \mu \mathrm{l}$ sampel DNA ditambahkan $1.998 \mu \mathrm{l}$ aquabides.

4. Amplifikasi fragmen DNA genom kecipir menggunakan teknik RAPD. Volume total untuk PCR adalah $10 \mu \mathrm{l}$, terdiri atas $5 \mu \mathrm{l}$ Go Taq green master mix PCR 2x, 2,25 $\mu \mathrm{l}$ nuclease free water, $0,25 \mu \mathrm{l} 50 \mu \mathrm{M}$ primer dan 2,5 $\mu \mathrm{l} 5 \mathrm{ng}$ DNA. DNA diamplifikasi menggunakan PCR thermal cycler BOECO.Pre-heating untai ganda DNA template pada suhu $95^{\circ} \mathrm{C}$ selama 1 menit, denaturasi pada suhu $95^{\circ} \mathrm{C}$ selama 45 detik, tahap penempelan (annealing) primer pada suhu $37^{\circ} \mathrm{C}$ selama 1 menit, pemanjangan primer (extension) pada suhu $72^{\circ} \mathrm{C}$ selama 1 menit 30 detik. Final extension pada suhu $72^{\circ} \mathrm{C}$ selama 7 menit.Diakhiri dengan holding pada suhu $4{ }^{\circ} \mathrm{C}$ selama 1 menit. Siklus diulang sebanyak 35 kali.

Pada tahap skrining digunakan 38 primer, kemudian dipilih 10 primer yang menghasilkan marka yang jelas dan polimorfik. Sekuen kesepuluh primer tersebut dapat dilihat pada Tabel 1.

Tabel 1. Sekuen primer hasil skrining

\begin{tabular}{rll}
\hline No. & Primer & Sekuen \\
\hline 1. & OPA 9 & 5'- GGGTAACGCC -3' \\
2. & OPA 10 & 5'- GTGATCGCAG -3' \\
3. & OPA 13 & 5'- CAGCACCCAC -3' \\
4. & OPA 18 & 5'- AGGTGACCGT -3' \\
5. & OPB 2 & 5'- TGATCCCTGG -3' \\
6. & OPB 3 & 5'- CATCCCCCTG -3' \\
7. & OPB 6 & 5'- TGCTCTGCCC -3' \\
8. & OPB 7 & 5'- GGTGACGCAG -3' \\
9. & OPB 10 & 5'- CTGCTGGGAC -3' \\
10. & OPB 11 & 5'- GTAGACCCGT -3' \\
\hline
\end{tabular}

Visualisasi marka RAPD. Produk PCR yang diperoleh dilihat menggunakan teknik elektroforesis yang di running menggunakan gel agarosa $1 \%$ dengan TBE $1 \mathrm{x}$ dan telah ditambahkan Florosafe DNA staining. Elektroforesis dilakukan selama 60 menit dengan tegangan $80 \mathrm{~V}$.

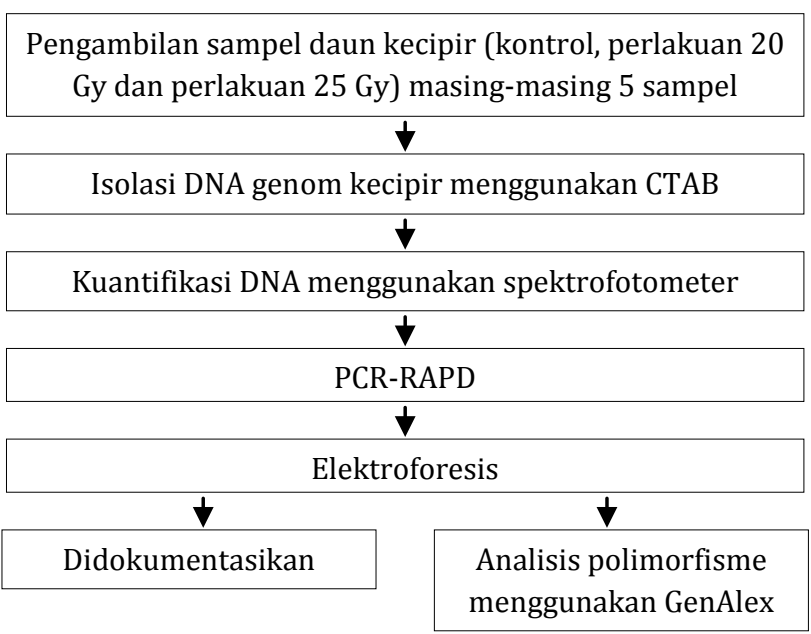

Gambar 1. Diagram alir penelitian

Visualisasi dilakukan pada paparan sinar UV menggunakan UV transluminator. Setelah itu, hasil didokumentasikan dengan kamera digital. 
Analisis polimorfisme DNA kecipir. Profil pola fragmen DNA masing-masing primer diskoring berdasarkan ada tidaknya fragmen menggunakan kode biner. Skor 1 jika ada fragmen dan skor 0 jika tidak ada fragmen tanpa memandang intensitasnya. Diagram alir penelitian dapat dilihat pada Gambar 1. Metode Analisis dilakukan secara deskriptif, berdasarkan ada tidaknya fragmen DNA yang dihasilkan. Pola fragmen RAPD diubah menjadi data biner. Setelah itu dilakukan analisis variasi genetic dan jarak genetic menggunakan program GenAlex 6.1.

\section{HASIL DAN PEMBAHASAN}

Berdasarkan hasil pengukuran menggunakan spektrofotometer, nilai kemurnian sampel DNA berkisar antara 1,235-1,732 (Å 260/Å280). Konsentrasi DNA genom hasil isolasi cukup tinggi, berkisar antara 900-7500 ng/ $\mu$ l (Tabel 2.). Pada tahap awal, dilakukan skrining primer untuk memperoleh primer yang menghasilkan fragmen yang polimorfik. Pemilihan primer dilakukan menggunakan tiga sampel yang dipilih secara acak diuji dengan 38 primer. Berdasarkan hasil skrining dipilih sepuluh primer, yaitu primer yang menunjukkan fragmen yang jelas dan polimorfik. Primer tersebut yaitu OPA 9, OPA 10, OPA 13, OPA 18, OPB 2, OPB 3, OPB 6, OPB 7, OPB 10,0PB 11 (Tabel 3). Sepuluh primer tersebut menghasilkan fragmen amplifikasi dengan intensitas yang tidak selalu sama.

Profil RAPD ketiga populasi kecipir menunjukkan perbedaan atau variasi. Persentase lokus polimorfik pada tiga populasi tersebut dapat dilihat pada Tabel 4 . Persen lokus polimorfik tertinggi ditunjukkan oleh perlakuan iradiasi 20 Gy sebesar 62,30\%, diikuti oleh perlakuan 25 Gy sebesar 54,10\% dan kontrol sebesar $47,54 \%$.

Tabel 2. Hasil kuantifikasi DNA genom kecipir

\begin{tabular}{|c|c|c|c|c|c|c|}
\hline No & Nama Sampel & $\begin{array}{c}\text { Konsentrasi } \\
(\mathrm{ng} / \mu \mathrm{l})\end{array}$ & $\begin{array}{c}\text { Kemurnian } \\
(\AA ̊ 260 / \AA ̊ 280)\end{array}$ & Å230 & Å260 & Å280 \\
\hline 1 & P0.1 & 7500 & 1,724 & 0,090 & 0,150 & 0,087 \\
\hline 2 & P0.2 & 3750 & 1,562 & 0,052 & 0,075 & 0,048 \\
\hline 3 & P0.3 & 5400 & 1,543 & 0,071 & 0,108 & 0,070 \\
\hline 4 & P0.4 & 1550 & 1,409 & 0,024 & 0,031 & 0,022 \\
\hline 5 & P0.5 & 2300 & 1,643 & 0,032 & 0,046 & 0,028 \\
\hline 6 & P20.1 & 3700 & 1,510 & 0,052 & 0,074 & 0,049 \\
\hline 7 & P20.2 & 2700 & 1,543 & 0,045 & 0,054 & 0,035 \\
\hline 8 & P20.3 & 900 & 1,636 & 0,013 & 0,018 & 0,011 \\
\hline 9 & P20.4 & 4250 & 1,545 & 0,059 & 0,085 & 0,055 \\
\hline 10 & P20.5 & 6150 & 1,519 & 0,091 & 0,123 & 0,081 \\
\hline 11 & $\mathrm{P} 25.1$ & 1050 & 1,235 & 0,026 & 0,021 & 0,017 \\
\hline 12 & $\mathrm{P} 25.2$ & 6500 & 1,625 & 0,083 & 0,130 & 0,080 \\
\hline 13 & P25.3 & 4850 & 1,732 & 0,055 & 0,097 & 0,056 \\
\hline 14 & P25.4 & 3050 & 1,605 & 0,049 & 0,061 & 0,038 \\
\hline 15 & $\mathrm{P} 25.5$ & 4350 & 1,673 & 0,054 & 0,087 & 0,052 \\
\hline
\end{tabular}

Keterangan: P0 = Kontrol, P20 = Perlakuan iradiasi 20 Gy, P25 = Perlakuan iradiasi 25 Gy, 1-5 = Nomor sampel

Variasi genetik juga dapat dilihat dari nilai heterozigositas, yaitu mengacu kepada adanya alel yang berbeda pada satu atau lebih lokus di antara kromosom homolog. Nilai heterozigositas ketiga populasi sampel dapat dilihat pada Gambar 2 .

Nilai heterozigositas tertinggi yaitu pada perlakuan 20 Gy. Sedangkan nilai heterozigositas terendah ada pada tanaman kontrol. Private bands paling tinggi juga pada perlakuan $20 \mathrm{~Gy}$.

Nilai $\mathrm{Na}$ dari ketiga populasi $>1$ dengan rata-rata 1,273. Nilai Ne ditentukan oleh jumlah langsung berkisar 1-n alel. Rata-rata Ne memenuhi persyaratan yaitu 1,359. Nilai variasi genetik total populasi adalah 0,211 . Nilai variasi genetik tanaman kontrol sebesar 0,194, perlakuan 20 Gy sebesar 0,236, perlakuan 25 Gy sebesar 0,202. Variasi genetik tertinggi terdapat pada perlakuan 20 Gy. Nilai variasi genetik tidak bias rata-rata total populasi sebesar 0,263 dengan nilai rata-rata tiap populasi pada tanaman kontrol sebesar 0,243, perlakuan 20 Gy sebesar 0,295 dan perlakuan 25 Gy sebesar 0,252. Nilai variasi tidak bias memenuhi persyaratan karena berada diantara 0-1. Nilai terendah jarak genetik pada biased sebesar 0,111 yaitu pada perlakuan 20 Gy dengan perlakuan 25 Gy dan nilai tertinggi sebesar 0,155 pada kontrol dan perlakuan 25 Gy. Sedangkan jarak genetik pada perhitungan unbiased nilai terendah terdapat pada perlakuan 20 Gy dengan perlakuan 25 Gy sebesar 0,012 dan nilai tertinggi pada kontrol dengan perlakuan 25 Gy sebesar 0,069. Identitas genetik berdasarkan perhitungan biased yang memiliki nilai terendah adalah kontrol dengan perlakuan 25 Gy sebesar 0,856 dan nilai tertinggi sebesar 0,895 antara perlakuan 20 Gy dengan perlakuan 25 Gy. Sedangkan perhitungan unbiased nilai terendah terdapat pada kontrol dengan perlakuan 25 Gy sebesar 0,933 dan tertinggi pada perlakuan 20 Gy dengan 25 Gy sebesar 0,988 (Tabel 6.).

Jarak genetik intrapopulasi dapat dilihat melalui PCA. Jarak genetik yang terjadi menjadi gambaran tentang variasi genetik yang ada. Jarak populasi kontrol tidak terlalu jauh satu sama lain, perlakuan 20 Gy berjauhan satu sama lain, dan perlakuan 25 Gy ada tiga sampel yang jaraknya dekat tetapi ada pula yang jaraknya jauh (Gambar 3).

Hasil isolasi DNA memiliki nilai konsentrasi berkisar antara 900-7500 $\mathrm{ng} / \mu \mathrm{l}$ dengan nilai Nilai kemurnian Å260/Å280 berkisar antara 1,235-1,732. Menurut Sambrook et al. (1989), kisaran kemurnian yang dibutuhkan dalam analisis molekuler adalah 
Å260/Å280 1,8-2,0. Nilai Å260/Å280 menunjukkan perbandingan DNA dan protein (Weissbach dan Weissbach, 1988). Kemurnian DNA dapat ditentukan menggunakan perbandingan nilai densitas optik pada berbagai panjang gelombang. DNA murni diamati pada rasio Å260/Å280 nm pada kisaran 1,8.
Peningkatan rasio biasanya menunjukkan adanya RNA, sedangkan rasio dibawah 1,8 menandakan adanya kontaminasi protein atau fenol. Kontaminasi protein atau fenol dapat dilihat juga pada rasio Å230/Å260 dengan nilai lebih besar dari 0,5 (Clark and Christopher, 2001).

Tabel 3. Kemunculan fragmen pada primer hasil skrining

\begin{tabular}{|c|c|c|}
\hline Primer & Sampel & Ukuran fragmen yang dihasilkan (bp) \\
\hline \multirow{3}{*}{ OPA 9} & Kontrol & $350,500,600,1000$ \\
\hline & Perlakuan 20 Gy & $350,600,1000,1300$ \\
\hline & Perlakuan 25 Gy & $350,600,1000$ \\
\hline \multirow{3}{*}{ OPA 10} & Kontrol & 300,600 \\
\hline & Perlakuan 20 Gy & $300,350,400,600$ \\
\hline & Perlakuan 25 Gy & 400,600 \\
\hline \multirow{3}{*}{ OPA 13} & Kontrol & $500,800,1200$ \\
\hline & Perlakuan 20 Gy & 500,800 \\
\hline & Perlakuan 25 Gy & $500,800,1200$ \\
\hline \multirow{3}{*}{ OPA 18} & Kontrol & $350,500,600,1200,1600$ \\
\hline & Perlakuan 20 Gy & $300,350,450,500,600,1200,1600$ \\
\hline & Perlakuan 25 Gy & $300,350,450,500,600,700,1000,1200$ \\
\hline \multirow{3}{*}{ OPB 2} & Kontrol & $200,250,350$ \\
\hline & Perlakuan 20 Gy & $250,350,500,600$ \\
\hline & Perlakuan 25 Gy & $250,350,500,600,700$ \\
\hline \multirow{3}{*}{ OPB 3} & Kontrol & $350,450,600$ \\
\hline & Perlakuan 20 Gy & $300,350,450,650,700,1000$ \\
\hline & Perlakuan 25 Gy & $300,350,600,700,1000$ \\
\hline \multirow{3}{*}{ OPB 6} & Kontrol & $300,500,600,1400$ \\
\hline & Perlakuan 20 Gy & $300,500,600,700,1400$ \\
\hline & Perlakuan 25 Gy & $300,500,600,1400$ \\
\hline \multirow{3}{*}{ OРB 7} & Kontrol & $250,500,600,700,800,1400,1800$ \\
\hline & Perlakuan 20 Gy & $250,350,400,500,600,800,1000,1100,1800$ \\
\hline & Perlakuan 25 Gy & $250,500,600,800,1800$ \\
\hline \multirow{3}{*}{ OPB 10} & Kontrol & $350,600,800,1300$ \\
\hline & Perlakuan 20 Gy & $350,600,700,800,1200,1300$ \\
\hline & Perlakuan 25 Gy & $350,600,800,1200$ \\
\hline \multirow{3}{*}{ OPB 11} & Kontrol & $400,600,700,800$ \\
\hline & Perlakuan 20 Gy & $400,600,700,800$ \\
\hline & Perlakuan 25 Gy & $300,400,600,700$ \\
\hline
\end{tabular}

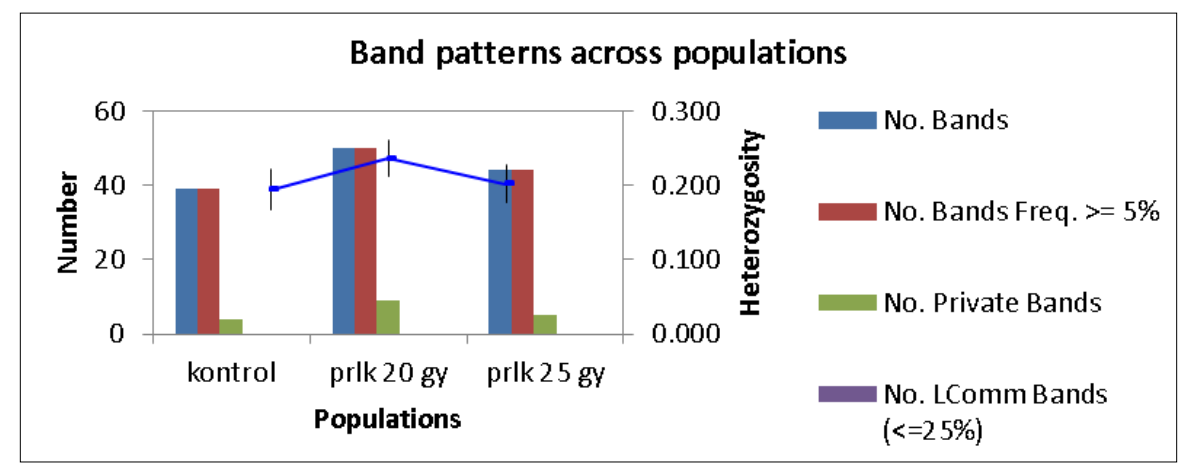

Gambar 2. Histogram nilai heterozigositas pada tiap populasi kecipir

Tabel 4. Presentase lokus polimorfik pada tiga populasi

\begin{tabular}{cc}
\hline Populasi & \% Polimorfisme \\
\hline Kontrol & $47.54 \%$ \\
Perlakuan 20 Gy & $62.30 \%$ \\
Perlakuan 25 Gy & $54.10 \%$ \\
\hline
\end{tabular}

Rasio yang diperoleh berada dibawah 1,8, hal ini dimungkinkan karena DNA terkontaminasi oleh protein. Menurut Innis et al. (1990), amplifikasi PCR tidak dibutuhkan kualitas dan kuantitas DNA yang terlalu tinggi, sampel setidaknya memiliki sedikitnya
Tabel 5. Nilai frekuensi alel dan estimasi variasi genetik

\begin{tabular}{ccccccc}
\hline & $\mathrm{N}$ & $\mathrm{Na}$ & $\mathrm{Ne}$ & $\mathrm{I}$ & $\mathrm{h}$ & $\mathrm{uh}$ \\
\hline Mean & 5.000 & 1.273 & 1.359 & 0.312 & 0.211 & 0.263 \\
$\mathrm{SE}$ & 0.000 & 0.064 & 0.027 & 0.022 & 0.015 & 0.019 \\
\hline
\end{tabular}

Keterangan :

$\mathrm{N}$ : jumlah alel, Na: jumlah alel yang berbeda, Ne: jumlah alel yang efektif, I: indeks shanon, h: variasi genetik, uh : variasi genetik tidak bias

satu untai DNA utuh dengan kontaminan yang cukup encer sehingga tidak mengganggu polimerisasi. Menurut Zainudin (2006), tingkat kemurnian DNA yang dibutuhkan pada RAPD tidak perlu terlalu tinggi, teknik ini toleran terhadap tingkat kemurnian DNA 
yang beragam. Dalam metode PCR tetap dibutuhkan prosedur untuk meminimalkan kontaminan yang dapat mengganggu reaksi PCR seperti polisakarida dan metabolit sekunder. Hasil isolasi DNA sampel dapat digunakan untuk analisis selanjutnya, tetapi sebelumnya disamakan konsentrasinya. Hasil dilusi DNA menjadi $5 \mathrm{ng} / \mu \mathrm{l}$. Berdasarkan hasil skrining primer dipilih sepuluh primer, yaitu primer yang menunjukkan fragmen yang jelas dan polimorfik Primer tersebut yaitu OPA 9, OPA 10, OPA 13, OPA 18, OPB 2, OPB 3, OPB 6, OPB 7, OPB 10,OPB 11. Kondisi PCR yang digunakan yaitu pre-heating $95^{\circ} \mathrm{C} 1$ menit, denaturasi $95^{\circ} \mathrm{C} 45$ detik, annealing $37^{\circ} \mathrm{C} 1$ menit, elongasi $72^{\circ} \mathrm{C} 1$ menit 30 detik, elongasi akhir $72^{\circ} \mathrm{C} 7$ menit, penyimpanan $4^{\circ} \mathrm{C}$.

Tabel 6. Analisis Nei's biased and unbiased

\begin{tabular}{|c|c|c|c|c|}
\hline \multirow{3}{*}{ Nilai } & \multicolumn{4}{|c|}{ Nei's } \\
\hline & \multicolumn{2}{|c|}{ Jarak genetik } & \multicolumn{2}{|c|}{ Identitas genetik } \\
\hline & Biased & Unbiased & Biased & Unbiased \\
\hline \multirow{2}{*}{ Terendah } & Perlakuan 20 Gy dengan & Perlakuan 20 Gy dengan & Kontrol dengan & Kontrol dengan \\
\hline & Perlakuan 25 Gy $(0,111)$ & Perlakuan 25 Gy $(0,012)$ & Perlakuan 25 Gy $(0,856)$ & Perlakuan 25 Gy $(0,933)$ \\
\hline \multirow{2}{*}{ Tertinggi } & Kontrol dengan & Kontrol dengan & Perlakuan 20 Gy dgn & Perlakuan 20 Gy dgn \\
\hline & Perlakuan 25 Gy $(0,155)$ & Perlakuan 25 Gy $(0,069)$ & Perlakuan 25 Gy $(0,895)$ & Perlakuan 25 Gy $(0,988)$ \\
\hline
\end{tabular}

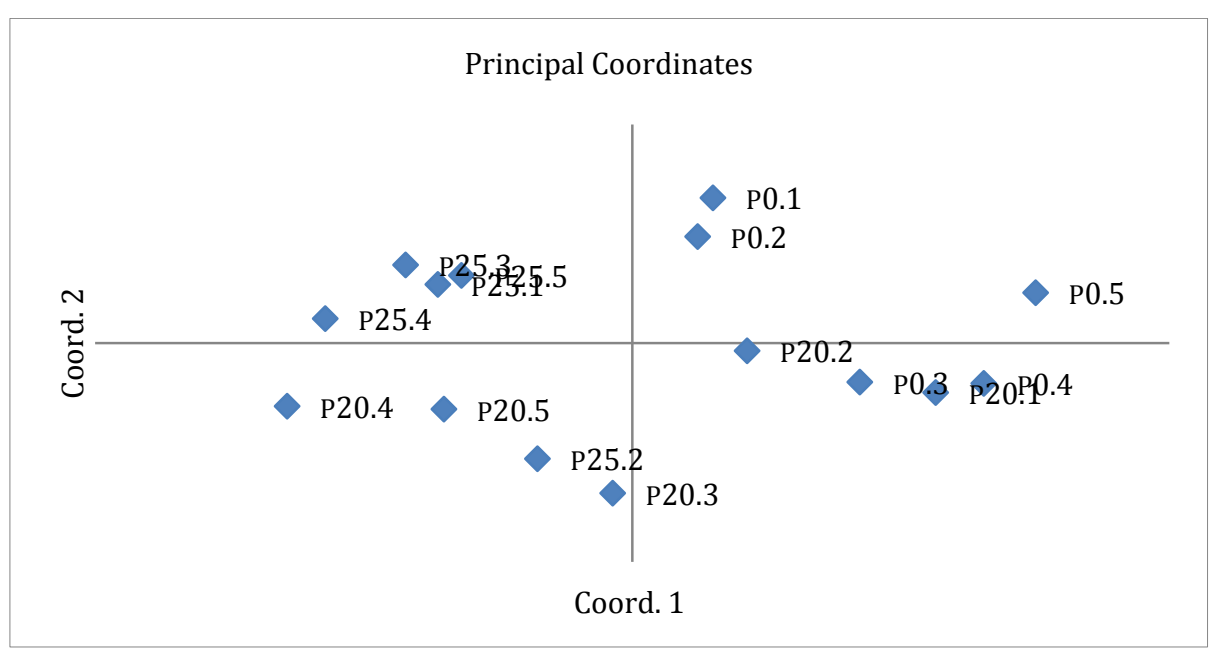

Gambar 3. PCA (Principal Coordinate Analysis)

Amplifikasi menggunakan OPA 9 menghasilkan marka RAPD berukuran 350 pb, 500 pb, 600 pb, 1000 pb dan 1300 pb. Beberapa sampel memiliki pola yang berbeda. Fragmen paling banyak muncul pada perlakuan kontrol. OPA 10 amplifikasinya menghasilkan marka pada ukuran 350 pb, 350 pb, 400 pb, 600 pb. Intensitas fragmen yang dihasilkan tidak terlalu jelas, namun masih dapat dibaca. Pola fragmen perlakuan 20 Gy dan 25 Gy memiliki pola yang berbeda dengan kontrol. Perlakuan 20 Gy memiliki polimorfisme yang lebih tinggi dibandingkan perlakuan 25 Gy.

Hasil amplifikasi menggunakan OPA 13 menghasilkan marka berukuran 500 pb, 800 pb dan 1200 pb. Pola fragmen pada semua sampel hampir sama kecuali pada kontrol sampel 4 dan 5 (P0.4 dan P0.5) dan perlakuan iradiasi 25 Gy sampel 1 dan 3 (P25.1 dan P25.3). Amplifikasi menggunakan OPA 13 menghasilkan marka yang cukup jelas. Hal ini dimungkinkan adanya fragmen yang menumpuk karena memiliki ukuran yang sama.

Amplifikasi menggunakan OPA 18 menghasilkan marka dengan ukuran 300 pb, 350 pb, 450 pb, 500 pb, 600 pb, 700 pb, 1000 pb, 1200 pb, dan 1600 pb. Pola fragmen antar perlakuan menunjukkan perbedaan. Sebagian besar fragmen yang dihasilkan tipis namun salah satu sampel menunjukkan dua fragmen yang sangat jelas dibandingkan dengan yang lain.

Amplifikasi dengan OPB 2 menghasilkan marka dengan ukuran 200 pb, 250 pb, 350 pb, 500 pb, 600 pb, dan 700 pb. Semua sampel menghasilkan fragmen kecuali sampel P0.2 tidak muncul fragmen. Fragmen cukup terlihat jelas, namun ada beberapa fragmen yang sangat tipis. Sampel yang diberikan perlakuan iradiasi 25 Gy memiliki pola fragmen yang lebih polimorfik dibandingkan dengan kontrol dan perlakuan 20 Gy.

Hasil amplifikasi menggunakan OPB 3 menghasilkan marka dengan ukuran 300 pb, 350 pb, $450 \mathrm{pb}, 600 \mathrm{pb}, 650 \mathrm{pb}, 700 \mathrm{pb}$, dan $1000 \mathrm{pb}$. Intensitas setiap marka berbeda, ada yang sangat jelas namun ada juga yang sangat tipis. Hal ini disebabkan karena jumlah DNA yang teramplifikasi pada tiap marka jumlahnya berbeda.

Amplifikasi menggunakan OPB 6 menghasilkan marka dengan ukuran 300 pb, 500 pb, 600 pb, 700 pb, dan 1400 pb. Fragmen yang dihasilkan memiliki pola yang hampir sama. Tingkat polimorfisme dilihat dari fragmen yang terbentuk tidak terlalu tinggi pada amplifikasi menggunakan primer ini, tetapi jumlah fragmen yang terbentuk banyak. 
Hasil amplifikasi menggunakan OPB 7 memiliki ukuran marka sebesar 250 pb, 350 pb, 400 pb, 500 pb, 600 pb, 700 pb, 800 pb, 1000 pb, 1100 pb, 1400 pb, dan 1800 pb. Tingkat polimorfismenya cukup tinggi dilihat dari pola fragmennya. Pola fragmennya berbeda pada tiap perlakuan. Perbedaan ini juga dimungkinkan karena terjadin mutasi akibat perlakuan yang diberikan.

Amplifikasi menggunakan OPB 10 menghasilkan marka dengan ukuran 350 pb, 600 pb, 700 pb, 800 pb, 1200 pb, dan 1300 pb. Fragmen berukuran 350 bp terlihat lebih tebal dibandingkan yang lain. Adanya penebalan pada fragmen tersebut kemungkinan terjadi karena DNA yang teramplifikasi jumlahnya banyak.

Amplifikasi dengan OPB 11 menghasilkan marka dengan ukuran 300 pb, 400 pb, 600 pb, 700 pb, dan 800 pb. Pola fragmen antara kontrol dan perlakuan iradiasi menunjukkan perbedaan.

Kesepuluh primer yang digunakan menghasilkan fragmen yang polimorfik. Terdapat satu sampel yaitu P0.2 yang tidak menghasilkan fragmen ketika diamplifikasi menggunakan OPB 2. Ketidakmunculan fragmen kemungkinan karena tidak terjadi penempelan primer. Dalam penelitian ini juga diamati perbedaan intensitas marka yang dihasilkan. Intensitas yang berbeda dapat disebabkan karena perbedaan kemurnian dan konsentrasi DNA cetakan. Selain itu adanya kontaminan seperti senyawa polisakarida, senyawa fenolik dan DNA cetakan yang konsentrasinya terlalu kecil sering menghasilkan fragmen yang redup atau tidak jelas (Weeden et al., 1992 dalam Poerba et al., 2008).

Pharmawati (2009) melaporkan bahwa pada konsentrasi DNA yang rendah justru menghasilkan pola yang konstan. Menurut Roslim et al. (2003), pemilihan primer RAPD berpengaruh terhadap polimorfisme pita yang dihasilkan, karena masingmasing primer memiliki situs penempelan tersendiri. Akibatnya pita DNA polimorfik yang dihasilkan setiap primer menjadi berbeda, baik dalam ukuran banyaknya pasang basa maupun jumlah pita DNA. Perbedaan muncul tidaknya fragmen menunjukkan adanya polimorfisme.

Persentase lokus polimorfik pada populasi kecipir kontrol adalah 47,54\%, kecipir dengan perlakuan iradiasi 20 Gy 62,30\%, kecipir dengan perlakuan iradiasi 25 Gy 54,10\%. Persentase lokus polimorfik tertinggi dijumpai pada perlakuan 20 Gy dan terendah pada tanaman kontrol. Hasil penelitian ini menunjukkan bahwa peningkatan dosis sinar gamma yang dipaparkan tidak berbanding lurus dengan peningkatan nilai polimorfisme. Nilai polimorfisme tanaman yang diberi perlakuan lebih tinggi jika dibandingkan dengan kontrol. Hal ini menunjukkan bahwa pemaparan sinar gamma menyebabkan peningkatan polimorfisme yang acak.

Pratiwi (2012) melaporkan bahwa studi RAPD dengan empat primer yang digunakan pada tanaman Globba leucantha menghasilkan nilai polimorfisme lebih dari 50\%. Menurut Chaturvedi dan Fujita (2006), polimorfisme dapat dapat dihasilkan karena perbedaan pola fragmen sebagai akibat penggunaan primer tertentu. Penelitian Harahap et al. (2013) menunjukkan rata-rata polimorfisme dari Garcinia mangostana L. yang telah diiradiasi sinar gamma dengan dosis $0,5,10,15,20,25,30,35,40,45,50$ Gy sebesar 93.9\% menggunakan 10 primer. Hal ini menunjukkan bahwa iradiasi sinar gamma efektif untuk mengubah DNA G. mangostana L.

Penelitian Roslim et al. (2003) pada kelapa menggunakan sepuluh primer memperoleh pita RAPD yang berukuran 250 pb sampai 3000 pb. Jumlah pita DNA berkisar 7 sampai 15, atau rata-rata menghasilkan 11 pita per primer. Polimorfisme pita DNA yang dihasilkan pada penelitian ini sebesar 78\% (87 pita) dari 112 total pita DNA yang diperoleh.

Hasil amplifikasi DNA karet dengan 40 primer menggunakan metode RAPD memperlihatkan keragaman genetik yang tinggi dengan nilai koefisien yang diperoleh sebesar 0.89-0.98 (Sa'adah, 2010). Menurut Mistiyatin (2007) dalam Sa'adah (2010), polimorfisme RAPD dihasilkan dari perbedaan sekuen pada satu atau kedua sisi situs penempelan primer.

Variasi genetik juga dapat dilihat dari nilai heterozigositas. Heterozigositas tertinggi terdapat pada perlakuan iradiasi $20 \mathrm{~Gy}$, sedangkan nilai heterozigositas terendah ditunjukkan oleh tanaman kontrol. Keunikan fragmen paling tinggi dijumpai pada perlakuan iradiasi $20 \mathrm{~Gy}$.

Nilai Na (jumlah alel yang berbeda) dari ketiga populasi $>1$ dengan rata-rata 1,273. Nilai Ne berkisar 1-2. Rata-rata Ne memenuhi persyaratan yaitu 1,359. Nilai variasi genetik total populasi adalah 0,211. Nilai variasi genetik tanaman kontrol sebesar 0,194, perlakuan iradiasi 20 Gy sebesar 0,236, perlakuan iradiasi 25 Gy sebesar 0,202. Variasi genetik tertinggi terdapat pada perlakuan iradiasi $20 \mathrm{~Gy}$. Nilai variasi genetik tidak bias rata-rata total populasi sebesar 0,263 dengan nilai rata-rata tiap populasi pada tanaman kontrol sebesar 0,243, perlakuan 20 Gy sebesar 0,295 dan perlakuan 25 Gy sebesar 0,252. Nilai variasi tidak bias memenuhi persyaratan karena berada diantara 0-1. Nagl et al. (2011) mengungkapkan variasi genetik diperoleh dari perhitungan jumlah lokus polimorfik dan persentasenya, number of alleles, effective number of alleles, dan Nei's gene diversity. Penelitian Nagl et al. (2011) terhadap Beta vulgaris (L.) menunjukkan nilai variasi genetik menggunakan RAPD Na sebesar 1,759, Ne 1,428, dan He 0,252.

Jarak genetik sesuai untuk mempelajari diferensiasi genetik pada suatu populasi karena jarak genetik dapat mengukur rata-rata jumlah gen yang berganti tiap lokus (Nei, 1979). Menurut Jin dan Chakraborty (1994) dalam Hartanti (2012) nilai kisaran jarak genetik adalah 0-1. Nilai jarak genetik tiga populasi tanaman kecipir yang diperoleh pada penelitian ini berada pada kisaran 0,08-0,32. Nilai jarak genetik terendah antara sampel P0.1 dengan 
P0.2, sampel P0.4 dengan P20.1 dan sampel P20.3 dan P25.2 sebesar 0,08. Sedangkan nilai jarak genetik tertinggi yaitu sebesar 0,32 ditunjukkan antara sampel P0.5 dan P20.4.

Nilai terendah jarak genetik biased sebesar 0,111 yaitu antara perlakuan iradiasi 20 Gy dengan perlakuan iradiasi 25 Gy dan nilai tertinggi sebesar 0,155 antara kontrol dan perlakuan iradiasi 25 Gy. Sedangkan jarak genetik pada perhitungan unbiased nilai terendah terdapat antara perlakuan iradiasi 20 Gy dengan perlakuan iradiasi 25 Gy sebesar 0,012 dan nilai tertinggi antara kontrol dengan perlakuan $25 \mathrm{~Gy}$ sebesar 0,069. Menurut Pandin (2009), apabila jarak genetik antarindividu semakin besar, maka variasi dari anggota populasi tersebut semakin tinggi.

Persamaan Nei digunakan untuk menentukan nilai jarak genetik dan kesamaan genetik atau identitas genetik. Identitas genetik adalah ukuran proporsi gen yang identik antara dua populasi dengan kisaran nilai 0-1 (Hartanti, 2012). Identitas genetik berdasarkan perhitungan biased yang memiliki nilai terendah adalah kontrol dengan perlakuan 25 Gy sebesar 0,856 dan nilai tertinggi sebesar 0,895 antara perlakuan iradiasi 20 Gy dan perlakuan iradiasi 25 Gy. Sedangkan perhitungan unbiased nilai terendah terdapat pada kontrol dengan perlakuan 25 Gy sebesar 0,933 dan tertinggi pada perlakuan 20 Gy dengan 25 Gy sebesar 0,988. Nilai identitas genetik rendah antar dua populasi menunjukkan bahwa kedua populasi tersebut berkerabat jauh, sedangkan nilai identitas genetik tinggi menunjukkan antarpopulasi tersebut berkerabat dekat.

\section{K E S I M P U L A N}

Iradiasi sinar gamma pada kecipir menghasilkan polimorfisme yang cukup tinggi dibandingkan kecipir yang tidak diinduksi sinar gamma. Sehingga keanekaragaman genetik yang didapatkan tinggi pula. Penggunaan sinar gamma efektif untuk memperoleh varietas mutan dalam rangka pemuliaan tanaman.

\section{DAFT AR REFERENSI}

Balai Besar Penelitian dan Pengembangan Bioteknologi dan Sumberdaya Genetik Pertanian. 2011. Pemanfaatan radiasi dalam pemuliaan tanaman. Warta Penelitian dan Pengembangan Pertanian. 33(1): 7-8.

Chaturvedi R, Fujita Y. 2006. Isolation of enhanced eicosappentaeonicacid producing mutans of Nannochloropsis oculata ST-6 using ethyl methane sulfonate induced mutagenesis techniques and their characterization at mRNA transcript level. Phycological Research. 54: 208-19.

Clark W, Christopher K. 2001. An introduction to DNA: spectrophotometry, degradation, and the 'Frankengel experiment. In Karcher SJ, editor. Proceedings of the 22nd workshop/conference of the association for biology laboratory education (ABLE); 2001; University of Alberta; Alberta, Canada.

Doyle JJ, Doyle JL. 1990. Isolation of plant DNA from fresh tissues. Focus. 12: 13-15.

Harahap F, Kamaruzaman J, Roedhy P, Nusyirwan, Syarifudin, Hasrudin. 2013. Mangosteen DNA analysis (Garcinia mangostana L.) with molecular markers after gamma ray irradiation treatment. American-Eurasian Journal of Sustainable Agriculture. 7(2): 37-44.

Hartanti F. 2012. Profil RAPD kecipir (Psophocarpus tetragonolobus (L.)DC) hasil mutasi menggunakan etil metan sulfonat [skripsi]. Universitas Jenderal Soedirman-Purwokerto.

IAEA, 1977. Manual on mutation breeding. JointFAO/IAEA Div. of Atomic Energy in Food and Agriculture. Tech. Rep. Ser. 2nd ed. 119: 287.

Innis MA, Gelfand DH, Sninsky JJ, White TJ. 1990. PCR protocols a guide to methods and applications. California: Academic Press.

Koshy EP, Alex BK, John P. 2013. Clonal fidelity studies on regenerants of Psophocarpus tetragonolobus (L.) DC. using RAPD markers. The Bioscan. 8(3): 763-66.

Krisnawati A. 2010. Keragaman genetikdan potensi pengembangan kecipir (Psophocarpus tetragonolobus L.) di Indonesia). Jurnal Litbang Pertanian. 3: 29.

Nagl N, Ksenija TA, Andrea P, Zivko C, Dario D, Lazar K, 2011. Estimation of genetic variation among related sugar beet genotypes by using RAPD. Genetika. 43: 575-82.

Nair NV, Selvi A, Sreenivasan TV, Pushpalatha KN. 2002. Molecular diversity in Indian sugarcane cultivars as revealedby randomly amplified DNA polymorphisms. Euphytica. 127: 219-25.

Nei, M., 1979. Genetic distance between populations. Naturalist 50. American Naturalist 106 (2), pp. 83 - 92.

Pandin DS. 2009. Keragaman genetik kultivar kelapa dalam mapaget (DMT dan dalam Tenga CDTA) berdasarkan penanda RAPD. Buletin Palma. 36: 18-19.

Pharmawati M. 2009. Optimalisasi ekstraksi DNA dan PCR-RAPD pada Grevillea spp. (Proteaceae). Jurnal Biologi. XIII: 12-16.

Poerba YS, Martanti D. 2008. Keragaman genetik berdasarkan marka random amplified polimorphic DNA pada Amorphophallus muelleri Bluem di Jawa. Biodiversitas. 9: 24549.

Pratiwi P. 2012. Analisis variasi genetik beberapa populasi Globba leucantha Miq. di Sumatera Barat dengan Random Amplified Polimorphic DNA (RAPD) [thesis]. Program Pasca Sarjana, Universitas Andalas-Padang.

Rismunandar. 1983. Kecipir: penghasil protein dan karbohidrat yang serbaguna. Bandung: Sinar Baru.

Roslim DI, Hartana A, Suharsono. 2003. Hubungan genetika populasi kelapa dalam Banyuwangi, Lubuk Pakam dan Paslaten berdasarkan analisis RAPD (Random amplified polimorphic DNA). International Journal of Agriculture and Biology. 6(1): 510.

Rukmana R. 2000. Kecipir budidaya dan pengolahan pascapanen. Yogyakarta: Kanisius.

Sa'adah N. 2010. Analisis sebaran genetik hasil persilangan tanaman karet RRIM 600 dan PN 1546 menggunakan teknik RAPD [skripsi]. Institut Pertanian Bogor-Bogor.

Sambrook J, Fritsch E, Maniatis T. 1989. Molecular cloning: a laboratory manual. 2nd ed. New York: Cold Spring Harbor Press.

Soeranto H. 2003. Peran iptek dalam pemuliaan tanaman untuk mendukung industri pertanian. Prosiding pertemuan dan presentasi ilmiah penelitian dasar ilmu pengetahuan dan teknologi nuklir P3TM-BATAN; 2003;Yogyakarta.

Sulistiyaningsih R, Aziz P, Woerjono M, Endang S. 2012. Variasi genetik anggrek alam Phalaenopsis amabilis (L.) Blume hasil iradiasi sinar gamma. Jurnal Ilmiah Aplikasi Isotop dan Radiasi. 8(1): 1-10.

Weissbach A, Weissbach H, 1988. Methode for plant molecular biology. California: Academic Press, Inc.

Williams JG, Kubelik AR, Livak KJ, Rafalski JA, Tingey SV, 1990. DNA polymorphisms amplified by arbitrary promers are useful as genetic markers. Nucl. Acid Res. 18: 6531-353.

Zainudin A. 2006. Optimasi proses PCR-RAPD anggrek Phalaenopsis sp. yang telah diperlakukan dengan cholchisine. Malang: Jurusan Agronomi Fakultas Pertanian Universitas Muhammadiyah. 